\title{
Water urbanism in Bogotá. Exploring the potentials of an interplay between settlement patterns and water management
}

\author{
Claudia Rojas ${ }^{\text {a, }}$, Bruno De Meulder ${ }^{\text {a }}$, Kelly Shannon ${ }^{\text {b }}$ \\ a Department of Architecture, University of Leuven, Belgium \\ ${ }^{\mathrm{b}}$ School of Architecture, University of Southern California, USA
}

\section{A R T I C L E I N F O}

\section{Article history:}

Received 24 November 2014

Received in revised form

10 March 2015

Accepted 29 March 2015

Available online 11 April 2015

\section{Keywords:}

Water management

Low-cost housing

Bogotá

Landscape urbanism

\begin{abstract}
A B S T R A C T
A paradigm shift in water management is recognized as a necessary and fundamental step for adaptation to climate change and crucial for furthering sustainability. In contexts of rapid urbanization, this paradigm shift is particularly challenged since social and environmental needs often come into conflict. In Bogotá, as other Latin-American cities, demands for new housing are increasing daily, while the overall housing deficit remains an unresolved problem. Currently, the city faces the challenges to deal with the pressure to continue to urbanize flood prone areas with low-cost housing projects and simultaneously protect these areas in view of flooding, which promise to increase with the predictions of climate change. In order to contribute to context-responsive solutions to the water and housing issues, this paper investigates the shifting relations between settlement patterns, water infrastructure and landscape in Bogotá's El Tintal watershed. This sub-watershed of the Bogotá River has a rich history of formal and informal low-cost housing. The critical reading of the landscape transformation of the El Tintal has shown how the water system interventions were and can be instrumental in different stages of development. This reading was the base to elaborate design investigations that could translate to spatial adaptation measures. This paper argues that "soft" water management tools can be part of a twofold strategy to create spatial quality and provide resilience for more qualitative future urban development.
\end{abstract}

(C) 2015 Elsevier Ltd. All rights reserved.

\section{Introduction}

Bogotá faces severe challenges in dealing with the pressure to develop flood prone areas with low-cost housing projects and simultaneously protect these areas in view of flooding, which promise to increase with the predictions of climate change. While sustainable urban water management is considered the most strategic and long-term requirement for climate change adaptation, the city's overall qualitative and quantitative low-cost housing deficit remains a major unresolved social issue. This paper investigates the shifting relations between water management and settlement patterns in Bogotá's western urban edge and proposes design strategies that have the potential to increase resilience, upgrade the spatial quality of low-income neighborhoods and provide space for new low-cost housing.

\footnotetext{
* Corresponding author. Kasteelpark Arenberg 51, 3001 Heverlee, Belgium.

E-mail addresses: claudia.rojasbernal@student.kuleuven.be (C. Rojas), bruno. demeulder@isro.kuleuven.be (B. De Meulder), skshanno@usc.edu (K. Shannon).
}

One of the largest obstacles to resolve the conflict between climate change-related issues and low-cost housing provision is the limited availability of land and its high cost. On the one hand, uncontrolled urbanization has rapidly consumed rural land and systematically encroached on water bodies, floodplains and wetlands, resulting in a fragmented ecosystem. Much of the development to the east of the Bogotá River has been built by filling wetlands, increasing impermeable surfaces and, in turn, has well been fitted with an inefficient sewer system. All this has led to a drastic reduction of landscape resilience. On the other hand, the high cost of land has both led to residential uses being continually pushed further and further out into the periphery and an impoverished quality of housing stock at the scale of urban design and architectural detailing. Large areas of self-constructed housing suffer the consequences of substandard urbanization, with a deficit of public space, social infrastructure, and low-level accessibility. Demands for new housing increase daily, while Bogotá's overall deficit remains unresolved. In 2011, the quantitative housing deficit for the city reached 258,046 dwelling units (Secretaria Distrital del Habitat, 2011). A first step towards increasing the resilience in the complexity of Bogotá's periphery should be the conversion of the 
contested relations between low-cost housing and environmental stress into a constructive interplay, through the sensitive design of new housing typologies that work with the logics of the site and in relation to fragile water realities.

The Bogotá River watershed covers 589,143 ha, which represents a mere $0.5 \%$ of Colombia's territory yet hosts $19 \%$ of the country's population. The Bogotá Region, which is not defined by juridical or administrative terms, contains the city and the 17 municipalities around it - with a population of more than 8.6 million - forms a sub-region in spatial, functional and geographical terms. The region geographically coincides with a plateau located in the Bogotá River basin [Fig. 1]. The high rate of unplanned development of Bogotá has exhausted its carrying capacity of the watershed in terms of water supply, land use and the water's selfpurification capacity. Water demands require the inter-basin transfer of water from the Orinoco watershed. Currently, $83 \%$ of the water consumed in Bogotá comes from the Paramo Chingazá, in the Orinoco watershed. The paramos is a high Andean ecosystem with a large water-storage capacity, coming from the plants and soils that are very sensitive to changes in temperature, wind and humidity. This ecosystem, the source of the Bogotá River, is threatened by livestock, agriculture and deforestation (DíazGranados, Navarrete, \& Suárez, 2005). In addition, water supply implies extensive exploitation of the aquifers that underlie the plateau, causing a decline in the groundwater level and land subsidence (Van der Hammen, 2006).

Land use patterns on the plateau have changed rapidly since the 1960s. Agricultural activities have been displaced by industrial uses and flower farming (CAR, 2006), jeopardizing long-term food security. The capacity of the only El Salitre wastewater treatment plant (WWTP) is $4 \mathrm{~m}^{3} / \mathrm{s}$, which is roughly $25 \%$ of Bogotá's total wastewater production. The city's sewer system also has serious shortcomings. Although a separate drainage system was installed in urban areas developed after 1965, in reality it actually functions as a combined system. Therefore, direct discharges of untreated wastewater and combined sewage overflows are common (Rodriguez et al., 2008).

Climate change, and particularly the strong precipitation variations associated with El Niño and La Niña (respectively high drought and increased rainfall), is bringing increased challenges to urbanization in the plain of the Bogotá River The existing studies on climate change estimate an increase of $2-4{ }^{\circ} \mathrm{C}$ for the end of the century. The paramos is the most threatened ecosystem as its special vegetation would be unable to adapt higher temperatures. These ecosystems would be also affected by the changes in rainfall patterns. The models show a possible rainfall reduction of around 10\%-20\% between 2041 and 2070 especially in the mountains were paramos are located and rivers are born. These changes will trigger a reduction of water availability. At the same time, a possible rainfall increase of around $20 \%-30 \%$ and more frequent occurrence of extreme rain in central areas of Cundinamarca will increase flood vulnerability (IDEAM et al., 2014).

The aforementioned developments raise numerous technical questions since a large part of the city's periphery has been built below the level of the Bogotá River. It implies that urban wastewater has to be pumped into the river. The wetlands that once regulated the river's dynamics have disappeared almost completely, and the effects of El Niña and La Niña will be magnified by climate change. What technical solutions would be the most appropriate to deal with these phenomena? Is it possible to restore landscape resiliency while exploiting the potential of local interventions? Can we restore the wet nature of the floodplain at Bogotá's western urban edge? Perhaps, most importantly, how can these interventions help to improve the quality of the urban environment for local communities?

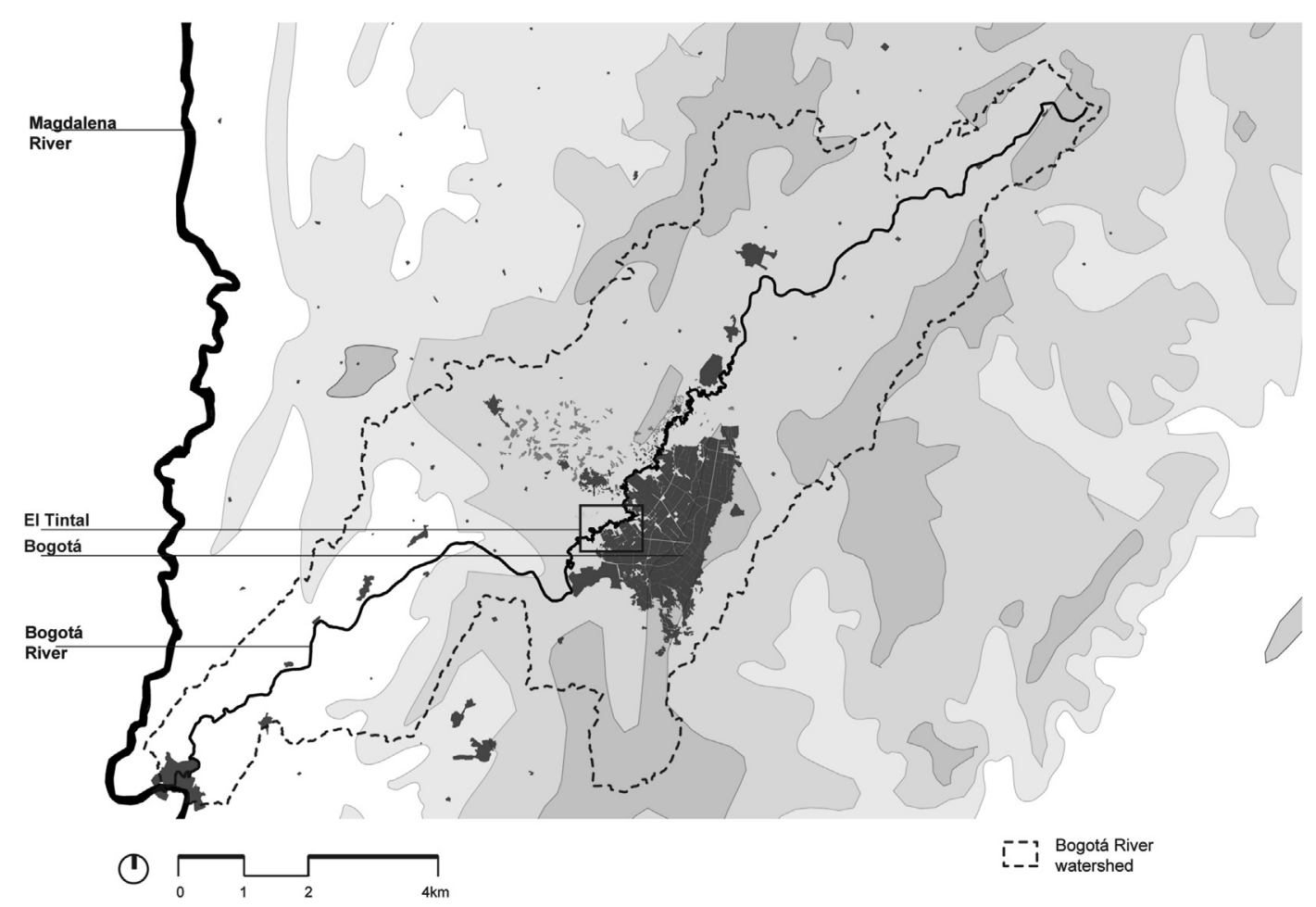

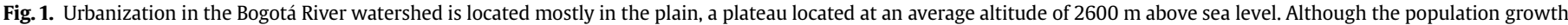

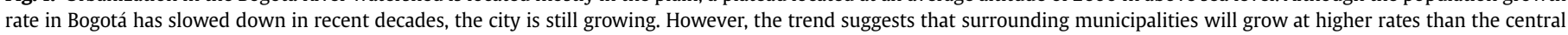
city. 


\section{Reading the El Tintal watershed through interpretative mapping: from wet floodplain to dry urbanization}

The research began from the premise that a deep understanding of the context, a detailed documentation and interpretation of a place are necessary in order to explore alternative adaptation measures to climate change that responds to the particular logics of a place. Using a case study methodology, the representative El Tintal sub-watershed was selected for its rich history of mass lowcost housing and its relation to the Bogotá River's landscape. The sub-watershed of 3405 ha is located in the southern part of the Sabana de Bogotá. It corresponds mostly with the Bogotá River's floodplain where 3 of Bogota's 14 remaining wetlands are located. In this area, the floodplain is wider, the groundwater level is high, the river speed is relatively slow and the meanders are broad. The area covers the southern part of the Kennedy and Bosa localities. These localities contain a large proportion of Bogotá's low-income population with serious deficiencies in infrastructure, social infrastructure and housing. In El Tintal sub-watershed, 803 ha are categorized as informal settlements in which urbanization have been driven by informal developers; 248 ha have been urbanized to host two recent macro-projects of low-cost housing, Ciudadela El Recreo and Ciudadela El Porvenir. The future development of other 142 ha, Ciudadela Campo Verde and Plan Parcial El Edén, are uncertain due to flooding risk. In the El Tintal sub-watershed, a separate sewer system has been installed, which consists of open storm-water canals and sewer pipes. However, the storm water system is nearing saturation levels due to pollution and dependence on a pumping station to evacuate the water into the Bogotá River.

The research project has employed interpretative mapping (Corner, 1999; Shannon, 2004) to analyze the case study in order to reveal the shifting relations between settlement patterns, water infrastructure and landscape. An analysis was made on how various attitudes through time and cultures towards the El Tintal watershed have been translated into the physical form. The making of a set maps combines different sources: anthropological and archeological studies, historical maps, old and contemporary aerial photographs and fieldwork. Through such a cartographic process, five periods in which productive systems had different relations with settlement patterns were clearly identified. In addition, it allowed the identification of the main problems as well as the areas of opportunities and where strategic interventions could have a broad, positive impact. The interpretative mapping was the base to propose design instruments that were able to translate adaptation measures in space, suggesting context-responsive solutions to the watershed's complex water and housing issues.

\section{Period 1: pre-Hispanic ridged fields: an indigenous landscape urbanism strategy}

During the pre-Hispanic era, the wet soils and natural cycles of flooding in the Sabana de Bogotá were broadly exploited for the construction of extensive agricultural systems. Ridged fields were built to manage extremely wet soils. These were located in the Bogotá River floodplain, on the terraces near the river and in the middle terrace located between the floodplain and mountain slope (Boada, 2006). The ridged fields and canals served as a buffer area, improved drainage and soil conditions, controlled temperature differences and provided an appropriate space for fish farming (Bernal, 1990). The ridged fields were composed of artificial earth mounds. The disposition of the mounds produced morphological variations that depended on their location in relation to the river and the soil geomorphology (Boada, 2006; Cavelier, 2006; Etayo,
2002). Archaeologist Ana Maria Boada identified 7451 ha in the Sabana de Bogotá where such ridged fields once existed [Fig. 2] with four morphological variations: checkerboard ridges, linear ridges, ridges parallel to the river and irregular ridges. Each variation performed different functions; while some structures worked well to retain water, others excelled at drainage (Boada, 2006). For instance, checkerboard ridges were found outside flood areas and disconnected from water bodies which might have indicated that they were used to retain water. The linear and parallel ridges were found in the floodplain, forming radiating lines from the exterior curves of the meanders or following interior curves. Their distribution suggested that they were used to drain excess water after floods and to take advantage of the sedimentation process to increase soil fertility. Irregular ridges were common in flood prone areas. Some of these were used extensively and provided an impressive area for cultivation (Boada, 2006).

The extension of the system and the need for periodic maintenance suggests that its construction took several centuries and depended upon on a complex social collaboration that implied strong leadership (Correa, 2004). At the same time, this form of production required a large population and provided the basis for the cazicazgos, a complex social political institution that was established during this period. In addition, archaeological evidence confirms the concentration of higher population densities along the Bogotá riverbanks. During the Herrera period (300 B.C. - 200 A.D.), the population settled along the western bank in small villages at relatively regular distances. Later they colonized the eastern bank. The villages grew during the Early Muisca (200-1000 A.D) and Late Muisca (1000-1600 A.D) periods. Some villages merged to form populations of major importance (Boada, 2006). Despite relative concentration, dispersed settlements persisted as proximity to ridged fields remained predominant as a morphology.

The Muiscas not only managed water to improve food production. As well, they had symbolic ties to water. Their religion was ruled by the Sun and Moon, considered as creators of the universe. Their society was one in which gods were worshiped and there were great rituals and sacrifices in privileged sites of nature, such as lakes, lagoons and hills (Correa, 2004). Bachué and Bochica were two of the most important symbolic representations of Muisca mythology and both were related to water. According to the myths, Bachué emerged from a lagoon with a boy in her arms; when the boy grew they procreated humanity and after they returned the lagoon, elderly and infertile. Bochica, the messenger of the Sun, civilized people and drained the waters that covered the Bogotá plateau. The beliefs surrounding these two mythical characters have become symbolically inscribed in the landscape and delineated its topography and hydrology. The myths both attempted to explain philosophical concerns, such the origin of the humankind and transformation within in the natural cycle, including the floods of the Sabana de Bogotá. The pseudo-science in fact coincides with the landscape geomorphology that was a lagoon for much of the Quaternary era (Correa, 2004).

The ridges in the El Tintal watershed are predominantly linear, which responded well to the need to drain the area. Most of the ridged fields have disappeared, while others remain a little known testimony to the careful and patient handling of water that defined the productive ecosystem and the settlement patterns that operated on a regional scale (as is the case of the ridge fields at the confluence of the Tunjuelito and Bogotá rivers). Some scholars argue that indigenous landscapes should be considered as archetypes of landscape urbanism (Shannon \& Manawadu, 2007). On the wet and fertile plateau, a water urbanism strategy, indeed emerged as a context-responsive solution to work with the forces of nature (Shannon, De Meulder, D'Auria, \& Gosseye, 2008). 


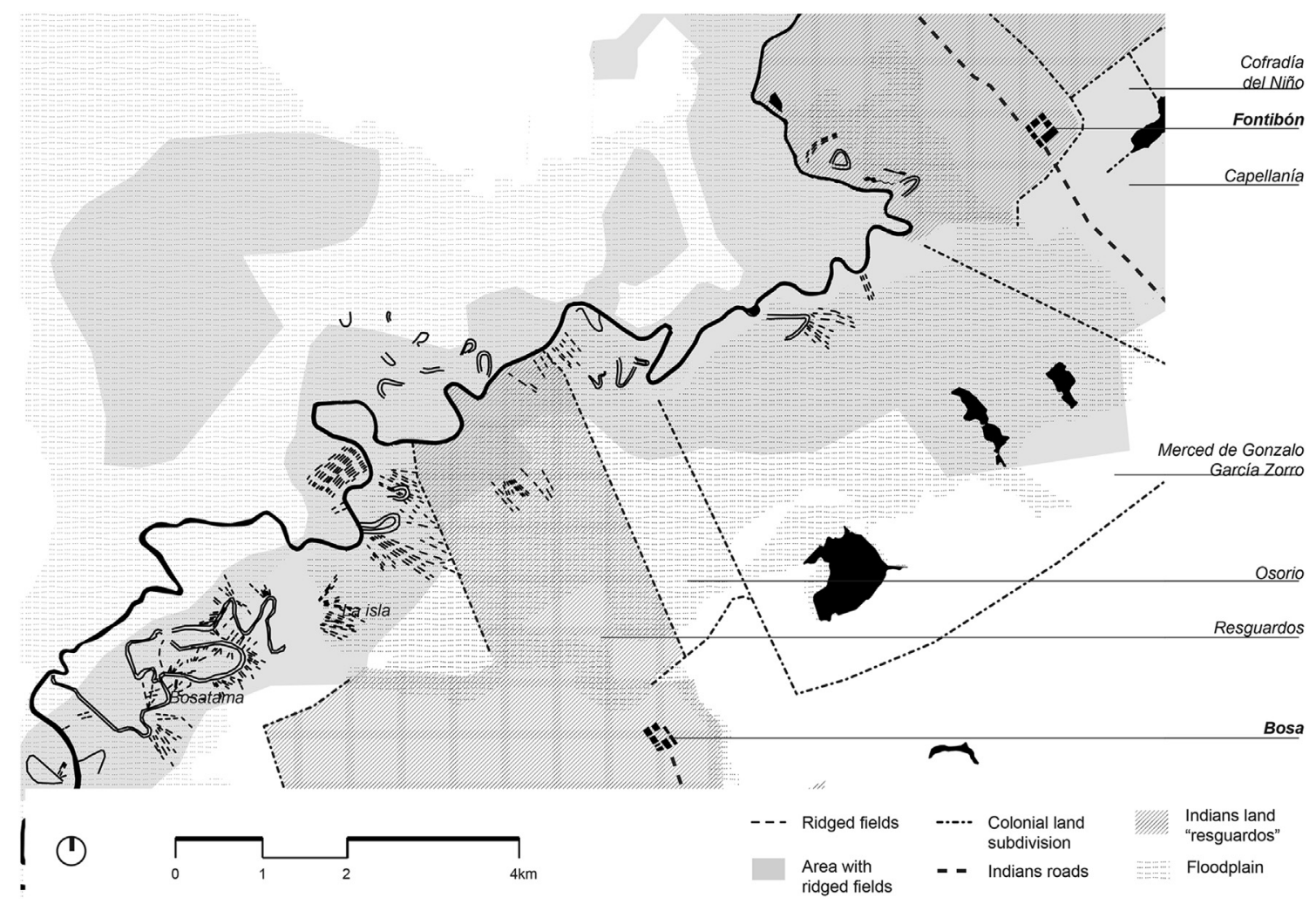

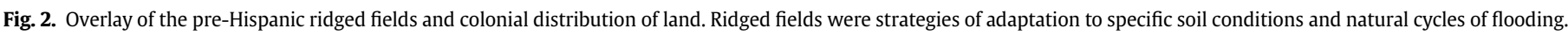

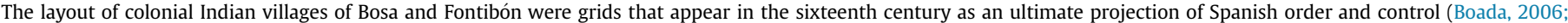
Etayo, 2002; Rodriguez, 2010).

\section{Period 2: "pueblos de indios": imported village and landscape isolation}

After the 116th century, the indigenous settlement pattern was radically replaced by either colonial Indian villages, called "pueblos de indios', or the colonial city. Such a division was an operation that served to control the territory through the domination of people. The colonial Indian villages intended to regroup the indigenous population into Spanish-type settlements in the areas with high population densities (Zambrano, 2004).The colonial city centralized new economic, cultural and social relations to administer the territory and organize space in function of power relations. In general, Indian villages occupied areas near the floodplain, while the colonial city "Santafé" (today Bogotá) nested itself on the higher safe land of the foothills, on the strip of alluvial near the river and areas with well-drained soils. The founding grid was projected and fit between the San Francisco and San Augustin Rivers, following the ordinances of Indian laws. The water supply and panoramic view of the plateau were instrumental in the site selection for Santafé, as well its relation to Indians settlements. Over time, the colonial city became isolated from the Bogotá River and relations with the rest of the territory were structured following Indian roads.

Following the founding of the colonial city of Santafé, the Spanish took possession of the remainder of the territory. In the area near the El Tintal watershed, they established the colonial Indian villages of Bosa in 1539 and Fontibon in 1594. Later in the twentieth century, these municipalities were incorporated into the administrative boundary of Bogotá. The conquerors that decided to populate the Sabana de Bogotá became "encomenderos", who enjoyed the rights to use the Indian labor, but did not have ownership rights over the land (Zambrano, 2004). However, the encomenderos appropriated land, consolidating a structure that gave way to estates. At the end of sixteenth century, a large part of Bogotá remained in indigenous hands in the form of reserves called resguardos, while another large part was given to the Spanish conquerors, Osorio, La Isla and Merced de Gonzalo García Zorro (Carrasquilla, 1989) [Fig. 2]. In the eighteenth century, as part of the Bourbon reforms, a number of regulations were implemented to reduce the encomenderos power and strengthen the State's presence and authority. The regulations included abolition of the exclusive exploitation of Indian labor. Therefore, other groups start to benefit from Indian labor and were able to acquire land. The Catholic Church was amongst those. A large part of their lands were received as donations from faithful individuals while another part was purchased (Delgado, 2010). The colonial center-periphery segregation and the concentration of property in a small proportion of the population endure until today.

The change of land tenure was accompanied by the progressive abandonment of traditional agricultural techniques and the introduction of modern, foreign methods. Arguably, the biggest impact was the systematic introduction of estates that gave priority to the land-use as grazing for livestock (Delgado, 2010). It is likely that cattle occupied the low-lying and easily flooded areas where the Muisca had installed a laborious canal system and where the most productive soils were located. It is also likely that the socio-political changes hindered social collaborations necessary to maintain and make use of this system. Crops were displaced to higher and drier land. However, the irrigation and drainage structures were not fully developed and the area's limited capacity did not allow for the rainonly irrigation system to thrive (Mora, 2011). New colonial villages grew slowly, over-exploiting the potential of the landscape, 
duplicating simple water supply systems and multiplying disturbances to the ecosystem.

\section{Period 3: ditches, canals and eucalyptus: drying the wet plain}

In spite of changes to the property and agricultural systems, innovation in water management techniques remained insignificant until the nineteenth century. At the end of that century, the government proposed numerous laws and projects in order to convert various wetlands and marshes into areas for agricultural and livestock production. For instance, in 1887, Law 23 established regulations for drying lakes in order to control floods and, increasing land for cultivation or livestock. Decree 40 of 1905, promulgated by the President Rafael Reyes, established that the State would promote the drying of lakes, lagoons, marsh and swamps (Guío \& Palacio, 2008). By 1861, Cundinamarca governor Justo Briceño proposed a project to reclaim about 6400 hectaresa of land by draining all the marsh and swamps of the Sabana de Bogotá. Fortunately, the project was suspended due to the nation's unfortunate civil war. Another project was built in the hacienda "'El Tintal", where' 192 hectaresa were reclaimed through the construction of several embankments, and of small reservoirs for summer irrigation in summer times and the drainage of wetlands (Parra, 1984). The construction of ditches enabled the occupation of frequently flooded lands. Ditches and canals were structured as a grid that also defined the estates boundaries [Fig. 3]. According to the Colombian Civil Code of 1887, water belongs to the State and is solely for public use; private individuals are allowed use, but cannot claim rights. However, private individuals can claim ownership of land. This legal distinction, where users could manipulate land and water led to the draining of wetlands for occupation, for instance (Guío \& Palacio, 2008).
The introduction of eucalyptus in the late nineteenth century was another large-scale measure to dry the land of the plateau. This fast growing eucalyptus globules was imported from southeastern Australia. It is an important source of timber for construction purposes, as well as for firewood and a medicinal plant. However, it also becomes invasive, requires high amounts of water and nutrients and displaces native species. Their damaging environmental effects have often been reported (Caliño-Cancela \& Rubido-Bará, 2013). In the Sabana de Bogotá, this species was highly instrumental in drying-out the soil (Van der Hammen, 2006). It was used indiscriminately by the owners of estates in order to "help in the task of drying the marshes" (Pardo, 1949). The eucalyptus was also planted in the mountains to recover upstream water resources. Recent studies agree in the need to replace the eucalyptus species of the Bogotá River floodplain, as well as in mountain areas (Van der Hammen, 2006).

\section{Period 4: improvising in Denial: the logics of informal territorial occupation}

Population grew slowly until the end of the 19th century. Density increased in the city center without significant urban expansion, mainly due to three natural constraints. Firstly was the existence of a belt of land called the ejidos designated as communal agriculture land. Secondly was the city's dependence on water supply from upstream mountain creeks. Thirdly were more than 50,000 ha of wetlands that covered the Sabana de Bogota until the middle of the 20th century (Van der Hammen, 2006). By 1880, the city reached the highest average density in its history with 400 persons per hectare (IEU, 2014). The high density and lack of appropriate sanitation infrastructure created serious health problems. In response, city authorities built new water supply infrastructure, sewer systems and working-class housing. These

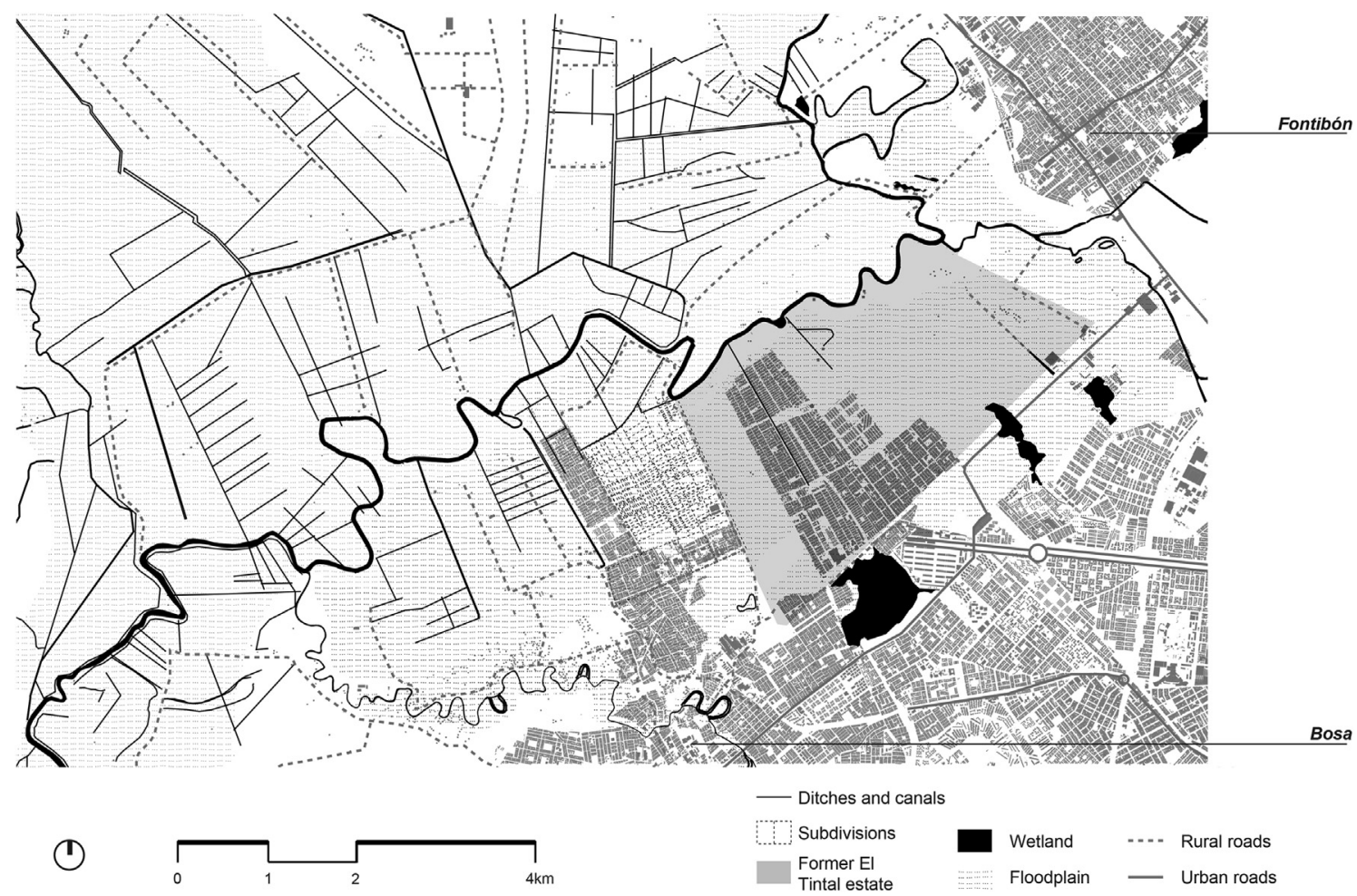

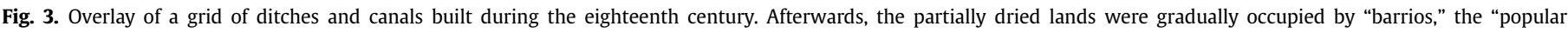
neighborhoods" that arose from self-construction. (IGAC, 1975, 1989). 
transformation started a new phase of urbanism based on sanitary concerns.

Bogotá's population began to grow steadily at the beginning of the 20th century. Modernization was an urgent need to cope with growing urban demands and to transform the country's economy. Beginning in the 1930s, modern urban plans delineated city's future growth. Between 1940s and 1950s, the Colombian urbanization process reached unprecedented dimensions. In 1953, Lauchlin Currie and Enrique Peñalosa developed a new plan for the city. The plan recommended annexing six surrounding municipalities, Bosa and Fontibon, Usaquén, Engativá, Suba, and part of Usme, to Bogotá. The main reason for the extension of the administrative boundary was the emerging informal urbanization dynamics. Another reason was the need to guarantee future water resources, for instance Usme was annexed because the Paramo Sumapaz was considered a potential source of water (Del Castillo Daza, 2008). This decision boosted the urbanization of the estates and pushed the city's expansion towards the river. At that time, agriculture land was available at an affordable price. The ability to acquire a plot and to have home ownership motivated low-income populations to move to these areas. Occupants first came either from congested tenement houses in the city center or were displaced from the countryside, by the violence of the 1950s.

The city's periphery, including the El Tintal watershed, was informally urbanized following the a predictable order of settlement, subdivision, housing building and only then infrastructure development (Tarchópulos \& Ceballos, 2005). The drainage system of ditches and canals functioned as the rudimentary framework for the settlements' morphology [Fig. 3]. Since the construction of infrastructure was the last stage of the process, the informal settlements preserved the original agricultural drainage system, often partially re-using it as an open sewer. Only after 1990s, when legalization was conducted by public entities, did the settlements formally gain access to piped water supply and waste-water collection systems.

For many of the inhabitants, the access to land and the imperative need for having a roof over one's head was more crucial than the guarantee of fresh water supply in terms of place selection for settlement. Once people had a plot, the struggle to gain access to fresh water supply was begun (Narvaez, 2009). A number of informal settlements obtained water from natural sources, such as creeks, streams or lagoons. Others depended on rudimentary infrastructures, such as the illegal perforation of urban pipelines, rural water supply systems, wells, water tank cars or high tanks (Narvaez, 2009). The legalization process often took more than a decade. To expedite the process, Bogotá's water and sewerage company EAAB (Empresa de acueducto y alcantarillado de Bogotá) promoted agreements with community organizations at the end of the 1990s. EAAB provided technical assistance and the community was in charge of building and funding the infrastructure (Narvaez, 2009). It demonstrates the capacity of communities to effectively and efficiently participate in the incremental infrastructural upgrading of their neighborhoods.

Paradoxically, the emergence of informal settlements went hand in hand with the sudden modernization of the city. One could indeed argue that setting the standard and norms (by modernism) simultaneously refers immediately to the substandard and categorically to the informal. Anyways, modernization allowed for the implementation of large-scale infrastructure, a fundamental jump in scale from previous developments. The growth of infrastructure and commodities attracted rural migrants looking for an improved quality of life. However, poorer migrants were excluded from the formal city (Ruiz, 2009). Consequently, they self-organized in what then (by definition) became informal settlements. Overall, urban density decreased, while urbanization spread over the plateau as a direct result of the process which generated severe environmental conflicts. For instance, it is estimated that in the last 60 years, nearly 49,000 ha of wetlands were dried (Viviescas, 2006). Nowadays, wetlands cover merely 1500 ha, about $2 \%$ of what originally existed.

Urbanization has reduced soil permeability and altered other physiological characteristics. During the last 20 years, the green areas in Bogotá have been reduced from 31 to 19\% (Díaz-Granados \& Camacho, 2012). The spread of urbanization without any consideration of its impact on water has also led to serious deterioration and fragmentation of the water system. Modernization and informality, as twin phenomena, have implied serious alienation from nature, strongly contrasting with the territory's indigenous landscape urbanism strategies. Over time, with the everincreasing expansion of formal regulations and modernization of economy and policy, development strategies have become purely technical, and as such, urbanism has become detached, step-bystep from the landscape.

\section{Period 5: hard infrastructure and housing tissues}

The interest to formally develop this area for housing dates back to 1953, when the municipality was annexed to Bogotá. Several studies for the Bogotá River flood control and environmental recovery developed between 1963 and 1988 studied drainage alternatives for these low lands. Not much of these plans was implemented, except emergency works between 1979 and 1981 that responded to the flood of 1979. During that year, floods acquired an unprecedented dimension after the break of a levee affecting not only rural areas, but also informal settlements located in the El Tintal watershed. In order to deal with the crisis, the environmental institution in charge of the regional water management, CAR (Corporación Autonoma Regional de Cundinamarca), set an emergency plan to give priority to the protection of inhabitants in vulnerable areas. The works comprised of the reconstruction of levees and dredging to increase the river section (CAR, 1981).

By 1991, EAAB formulated the project Santafe I. The project had two main objectives. One was to reduce flooding in the El Tintal watershed. The other was the construction of sewer networks in the periphery to enable the construction of large social housing projects (Hidroestudios, 1999). In turn, these housing projects responded to the creation of Metrovivienda in 1999, an agency that operates as public land bank. It provides serviced land on which private builders construct legal and affordable housing as to counter informality and increase dwelling quality. After several studies, Metrovivienda identified areas in the periphery that met the necessary conditions: cheap land prices, large plots and a small number of owners (Metrovivienda, 2011). Despite flood risks, El Recreo and El Porvenir, in the Tintal watershed, were selected to be developed as the first large social housing projects.

The water infrastructure works began in 2000, guided by a water management plan for the El Tintal watershed. This included the construction of the Canal Cundinamarca, a long canal parallel to the Bogotá River that collects rainwater from perpendicular canals and wastewater from new sewerage interceptors [Fig. 4]. These perpendicular canals follow the paths of former colonial ditches. After the construction of the drainage system, 248 ha of land became formally suitable for housing, including the projects $\mathrm{El}$ Recreo and El Porvenir, which together accommodated 15,918 lowcost housing units in addition to other private developments. In spite of the huge investment in formal infrastructure, the inhabitants nevertheless continue to endure flooding. In 2011, a major flood affected almost 50,000 people since the system depends on pump stations and maintenance is poor, demonstrating the shortcoming of traditional, hard-engineering approaches. 


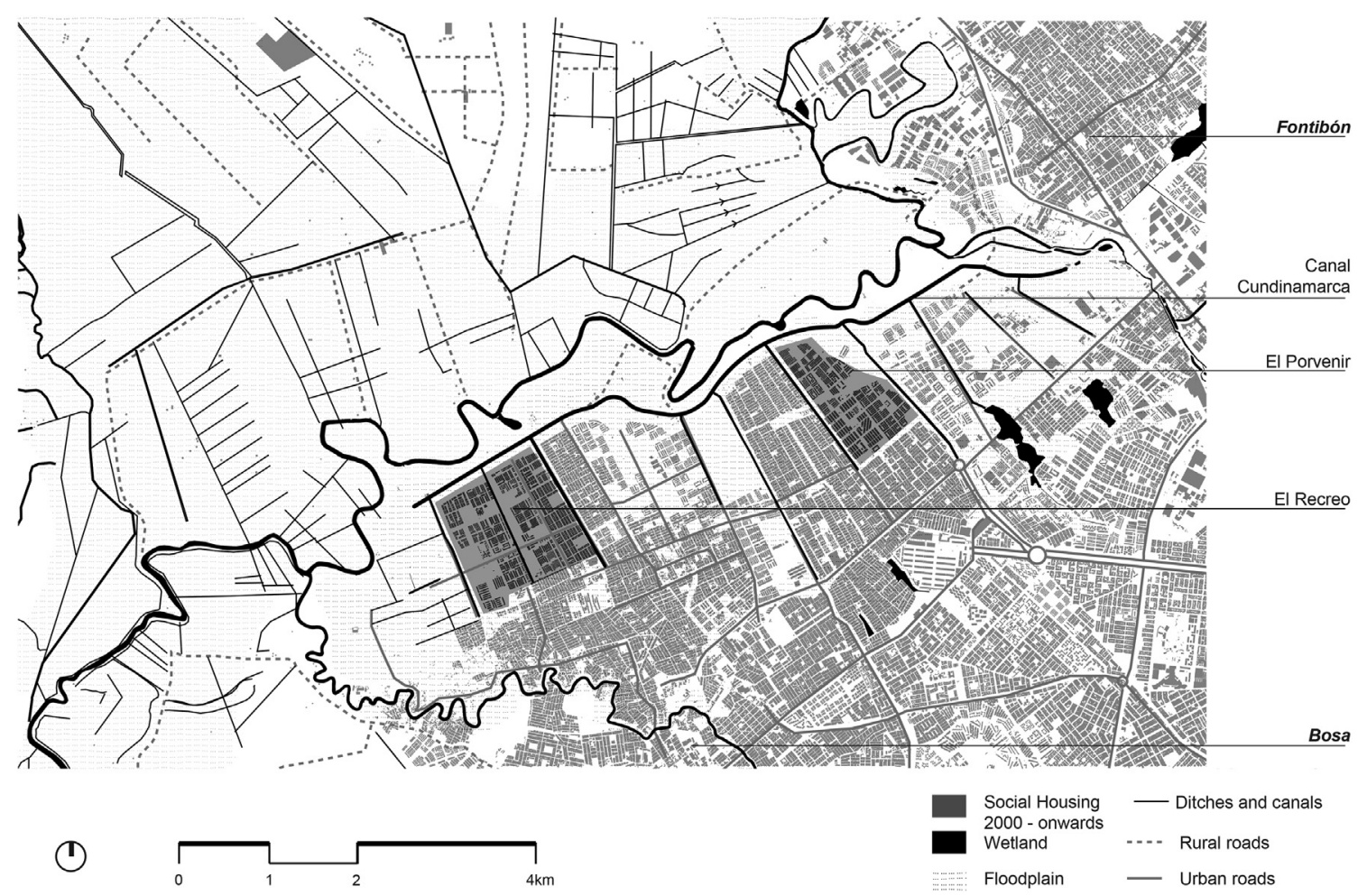

Fig. 4. A hard water infrastructure was inserted to reduce flood vulnerability. The mismatch of scale strengthens the contested relations with water

The challenges in the urban periphery are also the result of the overall spatial layout in which the elongated block is the predominant urban form. This is further conditioned by the addition of rows of small plots. The generic, elongated block is typically multiplied with an indifference towards the water system and the interface between public and private space is undefined (Tarchópulos \& Ceballos, 2005) [Fig. 5]. A new rainwater system has been inserted as a technical "hard" engineering solution, but due to its lack of integration with the urban form, it presently works as a barrier between different neighborhoods. In addition to the fear of
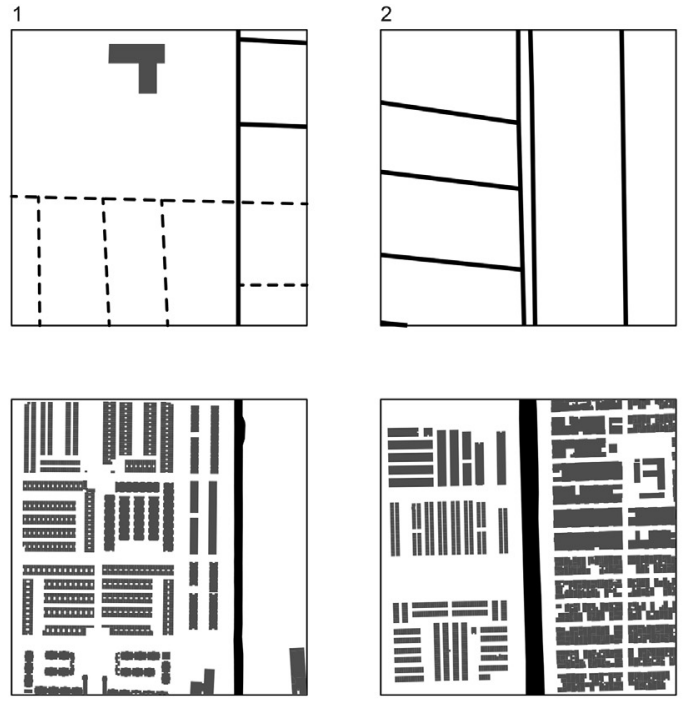
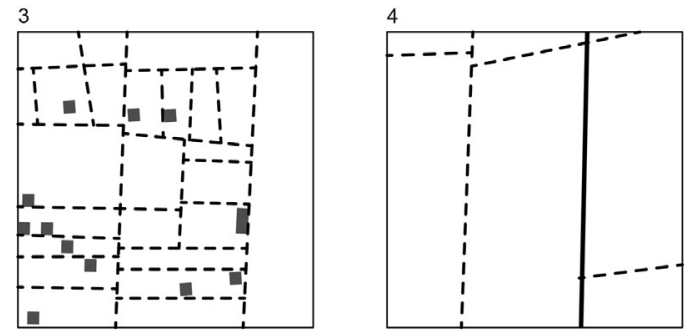

1989

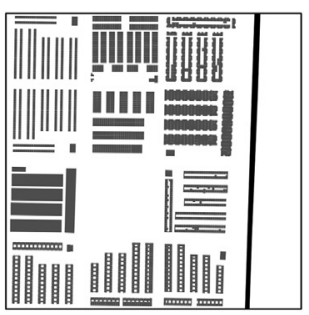

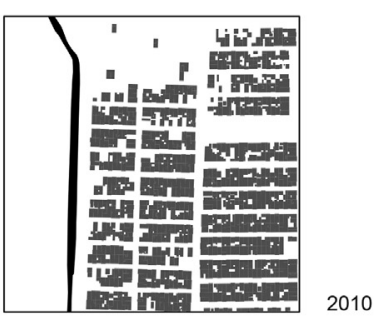

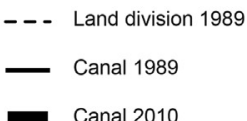

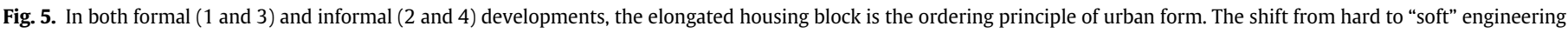
is an alternative to re-qualify the generic and monotonous urban form in the periphery. 
flooding, lack of activities and poor visibility of some areas along the canals creates insecure spaces where crime flourishes. The condition hinders social appropriation of the water system.

\section{Existing instruments and new tools}

Different tools have already been proposed to readjust the territory's urbanization patterns. After a century of modernization and alienation from nature, planning institutions recognize that it is necessary to once again embed the city in its landscape structure. On a larger scale, the Bogotá watershed land management plan, known by its Spanish acronym POMCA-2006 (Plan de ordenamiento $y$ manejo de la cuenca) ambitions to balance the restoration of the natural system with productive landscape uses (CAR, 2006). In addition, the CAR (Corporación Autónoma Regional de Cundinamarca) launched the first phase of a new project for the "Bogotá River's environmental recovery and flood control" in 2012, funded by the World Bank. The project, designed with a traditional hard engineering approach, is currently under construction. It basically consists of raising the dikes and widening the section of the river in order to increase flood protection, along with the construction of a linear park of variable with (from 30 to $60 \mathrm{~m}$ ) creating an ecological corridor, and the upgrading and expansion of El Salitre WWTP (CAR, 2013). It is however evident that higher dikes increase the pump dependency to evacuate all the urban waste water and even the water from tributaries. The more dikes, the less natural the system.

At the city scale, the new land use plan of Bogotá POT 2013 (Plan de ordenamiento territorial), issued by Decree 364 in August 2013, incorporates planning strategies for risk management and climate change. The plan promotes urban densification, the re-settlement of populations inhabiting high risk areas, an increase of environmentally protected areas (such as forests and parks) and the implementation of sustainable forms of construction, which includes sustainable drainage systems, infrastructure to ensure increased water retention and the creation of special parks for risk protection (POT, 2013). However, the implementation of these measures has been priorititized in what has been called the 'extended center,' losing an opportunity to re-qualify the built environment in the most densely populated peripheral areas.

Clearly, the above-mentioned instruments hold promise towards the reappearance and requalification of water in the city that should be articulated. However, their implementation requires the overcoming of the constraints imposed by existing built forms, as well as taking advantage of the opportunities that arise to restructure urban tissues. This is only possible however by designing at the intermediate scale. At this scale, environmental needs can be spatially translated and tied to social, cultural and economic dynamics. Relating social, economic and cultural forces of organization with urban design scale propositions have in many contexts proven to be a powerful combination in urban development, including Colombia. It could be qualified as the successful social urbanism approach of Medellin (Castro \& Echeverri, 2011).

In addition, also in Bogota, local communities themselves create innovative approaches for the restoration and management of water ecosystems. For instance, the pioneering project for the restoration of the La Vieja creek, promoted by the local community since 1984, was the basis for the recent creek restoration program promoted by the city government. The program aims to restore upstream creeks through the active involvement of the community (Jimenez, 2013). Another relevant experience is the intervention of the community in the restoration project of the wetland of Córdoba. It was initiated by neighbors preventing the implementation of an inefficient restoration project that had been proposed by the local water and sewerage company. Until now, this organization plays a decisive role in the implementation of any restoration project in the wetland (Sandoval, 2012). These approaches are a solid base to stimulate behavioral changes in society that could be intertwined with design strategies.

\section{Translating resilience into local design practice}

In a contemporary design research investigation for the El Tintal watershed, the existing instruments were taken one step further. The design strategies have two main aims: firstly, the redefinition of the wet and dry interface by transforming existing infrastructure into an instrumental landscape and secondly, the spatial definition of a new edge condition whereby urban tissues control the extension of urbanization at the threshold of important ecological structures. It is the intention to test these urban design strategies in further action research steps while engaging with community agencies. In that future phase, the relation between social and economic forces and urban design strategies will be established.

\subsection{Redefining the wet and dry interface}

Increasing landscape resilience in urban environments requires an intelligent redefinition of gradients that guarantees space for water under varying climatic conditions. The indigenous ridged fields are a remarkable example of a soft interface between water and land. Given the existing preconditions of the site, such a soft interface can be achieved by means of three complementary instruments. The first, sponge canals, takes advantage of the existing network of canals to increase retention. The second, water parks, provides space for water by defining floodable areas connected to a linear park proposed along the Bogotá River. The third, green and blue network guarantees ecological connectivity of the infrastructure by strengthening an expanded public realm.

The previous experience in the legalization processes of the 1990s demonstrated that local institutions have the capacity to engage communities in the construction of infrastructure works. Ongoing policies and programs show that different stakeholders are committed to environmental protection. Within the framework of Bogotá land use plan POT 2013, the city council created an institution in charge of risk management and climate change, called IDIGER (Instituto Distrital de Gestión de Riesgos y Cambio Climático). The institution develops technical studies and implements projects for risk mitigation; their ongoing studies include sustainable drainage systems and bioengineering techniques of slope stabilization. This institution can play a leading role in the implementation of the following proposed strategies.

\subsection{Sponge canals}

A system of canals defines the urban morphology since colonial times [Figs. 6 and 7]. However, they have only fulfilled technical functions. The transformation of the concrete canals into part of an instrumental landscape means that they can collect and dissipate urban storm-water runoff. Recent studies have pointed that types of drainage has an important effect in runoff. Impervious channelization increases the likelihood of runoff from limited amounts of rainfall (Gallo, Brooks, Lohse, \& McLain, 2013). Instead of depending completely on pumping stations, the concrete canals can be transformed and re-qualified as green structures to retain water. This transformation would allow multi-functionality, since the green structure could perform ecological functions and be integrated into and enliven public space and influence micro-climate. 


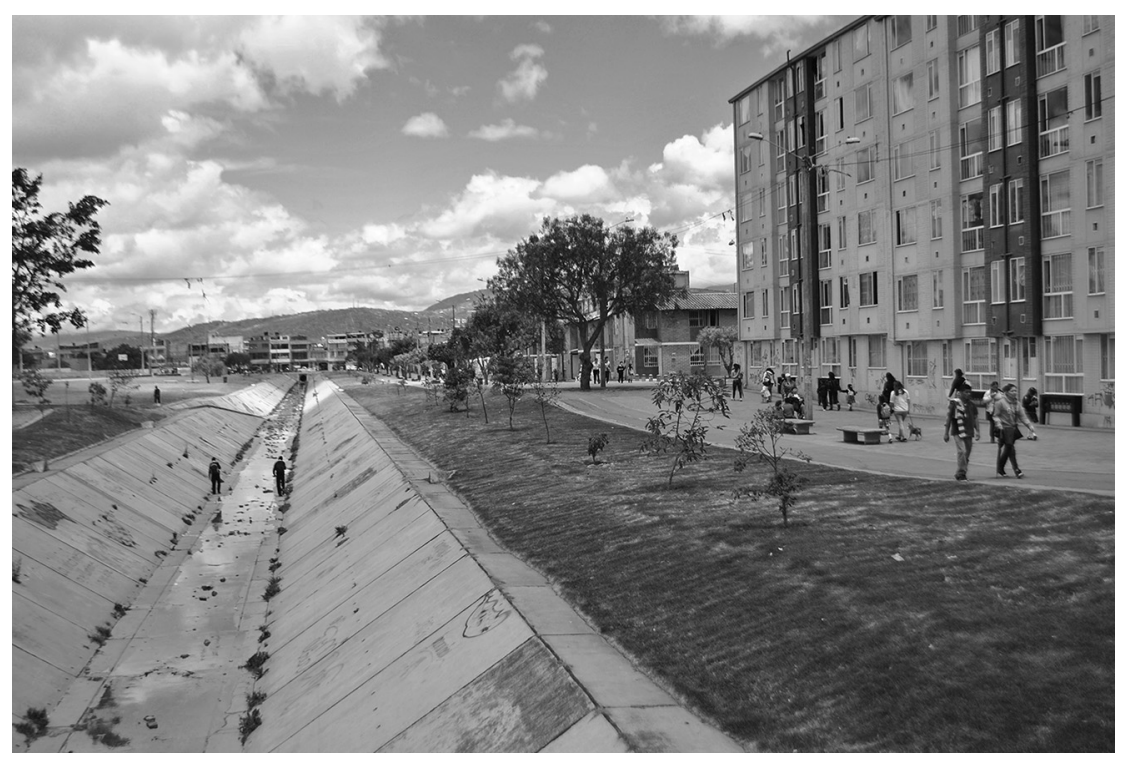

Fig. 6. The current water system has the potential to absorb the demands for public space and public equipment.

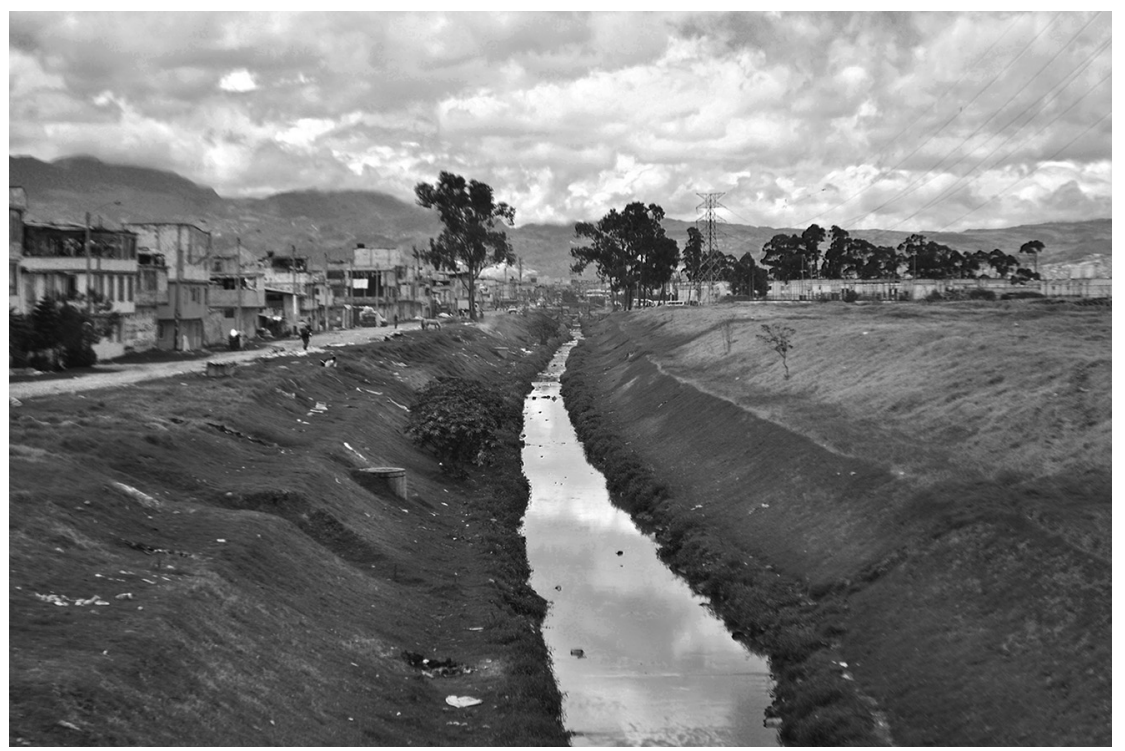

Fig. 7. The current water system has the potential to absorb the demands for public space and public equipment.

\subsection{Water parks}

Under-used open green areas have already been considered as potential parks for flood mitigation by the POT 2013. The incorporation of these areas into public space can increase the square meters of parks by compensating for the high-density of the periphery. Water parks can be designed for both permanent and temporary water retention. Water retention can be intertwined with programming when areas are also temporarily dry. In addition, flood mitigation would depend on the conservation of remaining wetlands, as well as on the incorporation of re-created wetlands that compensate a part of the original area of the ecosystems.

\subsection{Green and blue network}

One of the major investments in public space in the El Tintal was the construction of the Alameda el Porvenir, a pedestrian street planted with trees that also incorporates bike mobility. The long street of $18 \mathrm{~km}$ operates at the city scale, linking different neighborhoods. This infrastructure can be used to connect the sponge canals and water parks through re-design of the section and incorporation of sustainable drainage systems. Connectivity is essential to ensure sustainability of aquatic biota and terrestrial ecology and to increase resilience (Novotny, Ahern, \& Brown, 2010). 


\subsection{Defining the urban edge}

Edge redefinition provides new opportunities for the development of low-cost housing. Strategic interventions in water infrastructure can be coupled with new buildings and urban tissues that define a transition between the city and floodplain. The manipulation of topography can achieve different levels of protection. New social infrastructure can be strategically located to strengthen the public use of the green and blue network and take advantage of the re-structuring areas that is proposed in the UPZ structure.

\section{Conclusion}

The reading of the landscape transformation of the El Tintal demonstrated how water system interventions were and can be instrumental in different stages of development. These interventions have been and could constitute different layers that can be read and re-interpreted to support a new paradigm in water management. The pre-Hispanic soft engineered practices aligned productivity, culture and settlement patterns. During the Colonia, the import of foreign techniques and logics started a process of detachment from the landscape, unbalancing natural processes. Subsequently, the logics of modern engineering replaced natural dynamics in response to the pressing needs of a growing population. Development strategies became purely technical. Productivity responded more to economic interests so that the carrying capacity of the landscape and its cultural relationship with water became contested. The artificial logics of large infrastructure projects became the foundation that supported the development of the city, by regulating water cycles, supplying water and generating energy. The structural problematic of urbanization in Bogotá, such as the location of large living areas below the level of the river or the impossibility of relying exclusively on the resources of the Bogotá River watershed for water and food supply, involves an unbroken dependency of such large-scale works. However, adaptation to climate change demands a reduction on the dependency and a restoration of landscape resiliency through a more hybrid approach that incorporates soft and hard engineering strategies. What matters is how this combination is aligned with landscape dynamics to recover productivity, biodiversity and cultural relations that have been lost.

In this line, the discussion of a new paradigm in water management in Bogotá must begin with restoring the balance between its water system and urbanization dynamics. One of the persisting major challenges is the provision of new low-cost housing units and the upgrading of living conditions in the periphery. With the integration of the "soft" water related infrastructure, there is an opportunity to restructure urban tissues and to provide high quality public space. The re-incorporation of the cultural meaning of water and re-programming of uses should be intertwined with new water infrastructures. In the concluding part of this paper, we elaborated contextual urban design strategies that attempt to shape this intertwining and could serve as a first step-stone in a dialog with local community organizations to formulate innovative action plans that simultaneously deal with water management and with the improvement of their daily dwelling environment.

\section{References}

Bernal, F. (1990). Investigaciones arqueológicas en el antiguo cacicazgo de Bogotá (Funza, Cundinamarca). Boletín de Arqueología, 3, 31-48.

Boada, A. M. (2006). Patrones de asentamiento regional y sistemas de agricultura intensiva en Cota y Suba, Sabana de Bogotá (Colombia). Bogotá: Fundación de Investigaciones Arqueológicas Nacionales, Banco de la República.
Caliño-Cancela, M., \& Rubido-Bará, M. (2013). Invasive potential of eucalyptus globulus: seeed dispersal, seedling recruitment and survival in habitats surrounding plantations. Forest Ecology and Management, 305, 129-137.

CAR, Corporación Autónoma Regional de Cundinamarca. (1981). Programa de ampliación, profundización y rectificación del río Bogotá.

CAR, Corporación Autónoma Regional de Cundinamarca. (2006). Plan de ordenación y manejo de la cuenca hidrográfica del Río Bogotá. Resumen ejecutivo.

CAR, Corporación Autónoma Regional de Cundinamarca. (2013). Adecuación hidraúlica y recuperacion ambiental del Río Bogotá.

Carrasquilla, J. (1989). Quintas y estancias de Santa Fe y Bogotá. Bogotá: Banco Popular.

Castro, L., \& Echeverri, A. (2011). Bogota and medellin. Architecture and politics. Architectural Design, 81, 96-103.

Cavelier, I. (2006). Perspectivas culturales y cambios en el uso del paisaje. Sabana de Bogotá, siglos XVI-XVII. In F. Valdez (Ed.), Agricultura ancestral camellones y albarradas. Contexto social usos y retos del pasado y del presente (pp. 127-140). Quito: Ediciones Abya-yala.

Corner, J. (1999). The agency of mapping: speculation, critique and invention. In D. Cosgrove (Ed.), Mappings (pp. 211-252). London: Reaktion books.

Correa, F. (2004). El sol del poder: simbología y política entre los Muiscas del norte de los Andes. Bogotá: Universidad Nacional de Colombia.

Del Castillo Daza, J. C. (Ed.). (2008). Bogotá años 50: el inicio de la metrópoli. Bogotá Universidad Nacional de Colombia.

Delgado, J. (2010). La construcción social del paisaje de la sabana de Bogotá 1880 1890 (Master's thesis). Bogotá: Universidad Nacional de Colombia. Retrieved from http://www.bdigital.unal.edu.co/2703/1/468427.2010.pdf (accessed March 2014).

Díaz-Granados, M. A., \& Camacho, L. A. (2012). Valoración de cambios hidrológicos en la cuenca del río Bogotá. Revista de Ingeniería, Universidad de los Andes, 36 , $77-85$.

Díaz-Granados, M. A., Navarrete, J. D., \& Suárez, T. (2005). Páramos: hidrosistemas sensibles. Revista de Ingeniería, Universidad de los Andes, 22, 64-75.

Etayo, M. F. (2002). Evolución morfólogica del rio Bogotá durante la parte superior del Holoceno entre los municipios de Cota y Soacha (Sabana de Bogotá) y su relación con los "camellones prehispánicos" (Unpublished master's thesis). Bogotá: Universidad Nacional de Colombia.

Gallo, E. L., Brooks, P. D., Lohse, K. A., \& McLain, J. E. (2013). Land cover controls on summer discharge and runoff solution chemistry of semi-arid urban catchments. Journal of Hydrology, 485, 37-53.

Guío, C., \& Palacio, G. (2008). Bogotá: el tortuoso y catastrófico des-encuentro entre el río y la ciudad. In G. Palacio (Ed.). Historia ambiental de Bogotá y la Sabana, 1850-2005 (pp. 194-245). Bogotá: Universidad Nacional de Colombia/Instituto Amazónico de Investigaciones-IMANI.

Hidroestudios, S. A. (1999). Diseños detallados para el sistema troncal de alcantarillado sanitario y pluvial de la cuenca del Tintal en Santafé de Bogotá (Vol. 4) Empresa de acueducto y alcantarillado de Bogotá-ESP.

IDEAM, PNUD, Alcaldía de Bogotá, Gobernación de Cundinamarca, CAR, Corpoguavio, Instituto Alexander von Humboldt, Parques Nacionales Naturales de Colombia, MADS, \& DNP. (2014). El cambio climático en la Región Bogotá Cundinamarca y sus implicaciones para el desarrollo regional $(2011-2100)$. Plan Regional Integral de Cambio Climático para Bogotá Cundinamarca (PRICC). Retrieved from http://www.idiger.gov.co/documents/10179/275986 Policy+paper_06_Escenarios.pdf/b569d5b6-dbb4-4413-a1dc-48502aaf4663 (accessed March 2014).

IGAC, Instituto Geográfico Agustín Codazzi. (1975). Mapa de la Sabana de Bogotá.

IGAC, Instituto Geográfico Agustín Codazzi. (1989). Bogotá planchas 227-IV-C y 227 IV-D.

Jimenez, L. (2013). Las quebradas de Bogotá ya tienen quién las cuide. El Tiempo. Retrieved from http://www.eltiempo.com/colombia/bogota/ARTICULO-WEBNEW_NOTA_INTERIOR-12791786.html (accessed March 2014).

Metrovivienda. (2011). Una reflexion sobre la producción de vivienda social en Bogota 1998-2010. Bogotá: Metrovienda.

Mora, K. (2011). Prácticas agrícolas coloniales y degradación del suelo: el caso de Saquencipá. Revista Geográfica de América Central, 2(47E), 1-14. http://www revistas.una.ac.cr/index.php/geografica/issue/view/219/showToc (accessed March 2014)

Narvaez, G. E. (2009). Asentamientos humanos, agua y territorio. El proceso de expansión del sur de Bogotá (Master's thesis). Bogotá: Universidad Nacional de Colombia.

Novotny, V., Ahern, J., \& Brown, P. (2010). Water centric sustainable communities: Planning, retrofitting and building the next urban environment. Hoboken: Wiley.

Pardo, C. (1949). Haciendas de la Sabana. Bogotá: Editorial Kelly.

Parra, P. (1984). Aspectos de la agricultura y la desamortización en la Sabana de Bogoté (Unpublished thesis). Bogotá: Universidad Nacional de Colombia.

POT Plan de ordenamiento territorial. (2013). Decreto 364 de 226 de 2013. Alcaldía Mayor de Bogotá.

Rodriguez, D. L. (2010). Construcción del paisaje agrícola al sur de la sabana de Bogotá: un desafio al agua (Master's thesis). Instituto Politécnico de Tomar Universidade de Trás-os-Montes e Alto Douro. Retrieved from https://cld.pt/dl/ download/04d13faf-aded-414c-b1d7-4ed18d4c2c33/Gallo 2010 Bogota.pdf? public $=04 \mathrm{~d} 13 \mathrm{faf}-$ aded-414c-b1d7-4ed18d4c2c33 (accessed March 2014).

Rodriguez, J. P., Díaz-Granados, M. A., Camacho, L. A., Raciny, I. C., Maksimovic, C., \& Mclntyre, N. (2008). Bogotá's urban drainage system: context, research activities and perspectives. In Paper presented at the proceedings of the BHS tenth national hydrology, exeter. 
Ruiz, N. (2009). In M. Castillo (Ed.), Procesos urbanos informales y territorio (pp. 113-123). Bogotá: Universidad Nacional de Colombia.

Sandoval, D. (2012). Protected areas in the city, urban wetlands of Bogotá. Cuadernos de arquitectura y urbanismo, 6(11), 80-103.

Secretaria Distrital del Habitat. (2011). Encuesta Multipropósito Bogotá 2011-EMB. http://www.dane.gov.co/index.php/estadisticas-sociales/deficit-de-vivienda (accessed March 2014).

Shannon, K. (2004). Rhetorics and realities addressing landscape urbanism. Three cities in Vietnam (Doctoral dissertation). University of Leuven.

Shannon, K., De Meulder, B., D'Auria, V., \& Gosseye, J. (Eds.). (2008). Water urbanisms. Amsterdam: Sun.

Shannon, K., \& Manawadu, S. (2007). Indigenous landscape urbanism: Sri Lanka's reservoir \& tank system. JOLA Autum, 2007, 6-17.
Tarchópulos, D., \& Ceballos, O. L. (2005). Patrones urbanísticos y arquitectónicos en la vivienda dirigida a sectores de bajos ingresos en Bogotá. Bogotá: Pontificia Universidad Javeriana.

Van der Hammen, T. (2006). Génesis, evolución y estado actual del patrimonio natural y socio-cultural de los humedales de la Sabana de Bogotá. In A. Guarnizo, \& B. Calvachi (Eds.), Los humedales de Bogotá y la Sabana (pp. 17-49). Bogotá: Acueducto de Bogotá.

Viviescas, F. (2006). Bogotá: la ciudad del futuro con los humedales. In A. Guarnizo, \& B. Calvachi (Eds.), Los humedales de Bogotá y la Sabana. Bogotá: Acueducto de Bogotá.

Zambrano, F. (2004). Historia de la localidad de Tunjuelito: el poblamiento del valle medio del rio Tunjuelo. Bogotá: Editora Guadalupe. 